\title{
Kveim Test in leprosy: a clinical and histopathological evaluation
}

\author{
SURRINDER KAUR, * B KUMAR, ${ }^{*}$ Y P KATARIA ${ }^{\dagger}$ \\ \& R N CHAKRAVARTI* \\ *Postgraduate Institute of Medical Education and Research, \\ Chandrigarh, India and ${ }^{\dagger}$ East Carolina University School of \\ Medicine, Department of Medicine, Section of Pulmonary \\ Disease, Greenville, North Carolina 27834, USA
}

Received for publication 23 April 1981

\begin{abstract}
Summary The gross appearances and microscopic features of Kveim tests were studied in 21 North Indian leprosy patients. Of 6 patients with tuberculoid leprosy, 2 showed positive reactions and a close correlation between nodule formation and granulomatous histology. Of 15 patients with lepromatous leprosy, only 1 patient (who showed no evidence of a papule or induration at the Kveim test site) yielded a positive response microscopically. These findings suggest the occurrence of a low level of Kveim reactivity in North Indian leprosy patients. However, it is suggested that further studies with proper controls should be carried out to eliminate the possibilities of chance inclusion of subclinical leprotic skin lesion at the site of Kveim antigen injection and needle trauma in triggering or accelerating granulomatous inflammation.
\end{abstract}

\section{Introduction}

The specificity of Kveim test in sarcoidosis has been debated and challenged for years. ${ }^{1-9}$ More recently, a number of publications have strongly supported its specificity in sarcoidosis. ${ }^{10-13}$ However, using validated Kveim preparations, it has been concluded that positive Kveim reactions do occur in all varieties of leprosy but are infrequent, except in Chinese and Japanese patients who show a higher frequency of positive tests. ${ }^{14-18}$ This study was undertaken to test validated Kveim antigen CR-I ${ }^{11}$ in North Indian leprosy patients.

\section{Material and methods}

Twenty-one patients of different types of leprosy ${ }^{19}$ attending the leprosy clinic of the Nehru Hospital attached to the Postgraduate Institute of Medical 0305-7518/81/052329+07\$01.00 @ British Leprosy Relief Association 
Education and Research, Chandigarh, India, were tested with validated Kveim antigen CR-I. $0.15 \mathrm{ml}$ of the test material was injected on the forearm. The exact site was identified by measuring the predetermined distance from the India ink spot tattoed in the forearm skin. All of the patients had been tested with 1 unit of PPD (Serum Institute, Copenhagen), and only negative reactors were included in the study. The patients were thoroughly screened for evidence of active tuberculosis, sarcoidosis, or any other chronic disease.

Lepromin test was carried out with $0.15 \mathrm{ml}$ of standard lepromin (having 160-200 million bacilli $/ \mathrm{ml}$ ) on all the patients and was read after 4 weeks, and if negative, after 6 weeks. The test was considered negative if there was less than $4 \mathrm{~mm}$ induration.

Age, sex, duration of the disease, and treatment were not taken into consideration. None of the patients had received any steroid, immunosuppressive or other anti-inflammatory drugs within the past 3 months.

Biopsy specimens from Kveim antigen sites, irrespective of the induration, were taken after $40 \pm 2$ days and were stained with haematoxylin and eosin stains, and Fite-Faraco stain for the demonstration of acid-fast bacilli. The biopsies were graded as positive, equivocal, or negative according to the criteria of Siltzbach and Ehrlich ${ }^{20}$ and those of Mitchell. ${ }^{21}$ Biopsy specimens were separately screened by 2 different pathologists who were not aware of the type of study.

\section{Results}

Out of the 21 patients studied, 4 were polar tuberculoid (TT), 2 were borderline (BT), 10 belonged to the borderline lepromatous (BL) group, and 5 were of the polar lepromatous (LL) type. For purposes of discussion, BT patients have been included in the TT group and BL in the LL group, as shown in Table 1. Duration of the disease was more than 3 years in all patients, and each patient had taken the treatment for over 2 years.

Lepromin reaction was positive (induration of $4.5 \mathrm{~mm}$ or more) in all the TT and BT patients, and negative in all BL and LL patients.

The Kveim test was positive in 3 patients, 2 in the TT group (Figure 1) and 1 in the LL group (Figure 2). In the TT group both patients showed a nodule formation and positive histology, whereas in the LL group the positive histology was seen in the absence of any detectable induration (Table 1). In addition, the biopsies in 1 patient in the TT group and 2 in the LL group showed moderate chronic inflammatory cellular response with no specific granuloma formation. 
Table 1. The age, sex, type of leprosy, positive reactions, and histopathology

\begin{tabular}{|c|c|c|c|c|}
\hline No. & $\begin{array}{l}\text { Name/Age/Sex/Type of } \\
\text { Leprosy/Duration of disease }\end{array}$ & $\begin{array}{l}\text { Reaction to } \\
\text { Kveim Antigen }\end{array}$ & $\begin{array}{c}\text { Grouping of } \\
\text { patients for } \\
\text { study }\end{array}$ & $\begin{array}{l}\text { Histo- } \\
\text { pathological } \\
\text { findings }\end{array}$ \\
\hline 1 & $\mathrm{~L} / 40 / \mathrm{M} / \mathrm{BT} / 4 \mathrm{yrs}$ & + & TT & - \\
\hline 2 & $\mathrm{RSS} / 35 / \mathrm{M} / \mathrm{TT} / 3$ yrs & - & TT & \pm \\
\hline 3 & $\mathrm{D} / 25 / \mathrm{M} / \mathrm{TT} / 5 \mathrm{yrs}$ & + & TT & + \\
\hline 4 & $\mathrm{RN} / 35 / \mathrm{M} / \mathrm{BT} / 3$ yrs & - & TT & - \\
\hline 5 & $\mathrm{SK} / 35 / \mathrm{F} / \mathrm{TT} / 5$ yrs & - & TT & + \\
\hline 6 & $\mathrm{AK} / 45 / \mathrm{F} / 55 / 4$ yrs & + & $\mathrm{TT}$ & - \\
\hline 7 & $\mathrm{AR} / 45 / \mathrm{M} / \mathrm{BL} / 8$ yrs & - & LL & - \\
\hline 8 & $\mathrm{SL} / 40 / \mathrm{M} / \mathrm{BL} / 3$ yrs & + & LL & - \\
\hline 9 & $\mathrm{MPN} / 50 / \mathrm{M} / \mathrm{BL} / 6$ yrs & - & LL & - \\
\hline 10 & $\mathrm{RD} / 45 / \mathrm{M} / \mathrm{BL} / 4 \mathrm{yrs}$ & - & LL & - \\
\hline 11 & $\mathrm{JS} / 55 / \mathrm{M} / \mathrm{BL} / 3 \mathrm{yrs}$ & - & LL & - \\
\hline 12 & $\mathrm{~S} / 20 / \mathrm{F} / \mathrm{BL} / 4$ yrs & - & LL & - \\
\hline 13 & $\mathrm{SS} / 50 / \mathrm{M} / \mathrm{BL} / 4$ yrs & - & $\mathrm{LL}$ & - \\
\hline 14 & $\mathrm{~K} / 35 / \mathrm{F} / \mathrm{BL} / 5$ yrs & - & LL & \pm \\
\hline 15 & $\mathrm{BS} / 60 / \mathrm{M} / \mathrm{BL} / 10$ yrs & - & LL & \pm \\
\hline 16 & $\mathrm{~L} / 20 / \mathrm{F} / \mathrm{BL} / 4$ yrs & - & LL & + \\
\hline 17 & $\mathrm{H} / 35 / \mathrm{M} / \mathrm{LL} / 5 \mathrm{yrs}$ & - & LL & - \\
\hline 18 & $\mathrm{KD} / 45 / \mathrm{F} / \mathrm{LL} / 5 \mathrm{yrs}$ & - & LL & - \\
\hline 19 & $\mathrm{LB} / 20 / \mathrm{M} / \mathrm{LL} / 5$ yrs & - & LL & - \\
\hline 20 & $\mathrm{RR} / 30 / \mathrm{M} / \mathrm{LL} / 5 \mathrm{yrs}$ & - & LL & - \\
\hline 21 & $\mathrm{BR} / 40 / \mathrm{M} / \mathrm{LL} / 10$ yrs & - & LL & - \\
\hline$\overline{B T}$ & Borderline tuberculoid. & LL & Polar lepromatous. & \\
\hline BL & Borderline lepromatous. & TT & Polar Tuberculoid. & \\
\hline- & Negative & + & \multicolumn{2}{|c|}{ Induration up to $5 \mathrm{~mm}$. } \\
\hline
\end{tabular}

Histopathological changes:

- $\quad$ None to mild. Nonspecific inflammation.

$\pm \quad$ Equivocal. Moderate inflammation with no classical granuloma formation.

$+\quad$ Positive. Classical epithelioid granuloma with or without giant cells.

\section{Discussion}

Since the first use of test material reported by Williams and Nickerson, ${ }^{22}$ subsequently named Kveim antigen, ${ }^{23}$ conflicting reports appeared in the literature regarding the specificity of Kveim test. While some authors accepted false positive Kveim test rate in the range of $<$ or $=3 \% \%^{6,24,25}$ others claimed much higher positive rates in a variety of diseases other than sarcoidosis. ${ }^{4,14,15,24,26-29}$ The lack of specificity of Kveim test was, in most part, attributed to unvalidated Kveim preparations. ${ }^{30}$ Further, careful testing of Kveim antigens prepared from different sarcoidosis tissues have shown that less than half of these Kveim preparations may turn out to be specific enough as to warrant its use as a diagnostic reagent. ${ }^{17}$ Although a number of recent publications strongly support the specificity of Kveim test, ${ }^{10-13}$ the response 


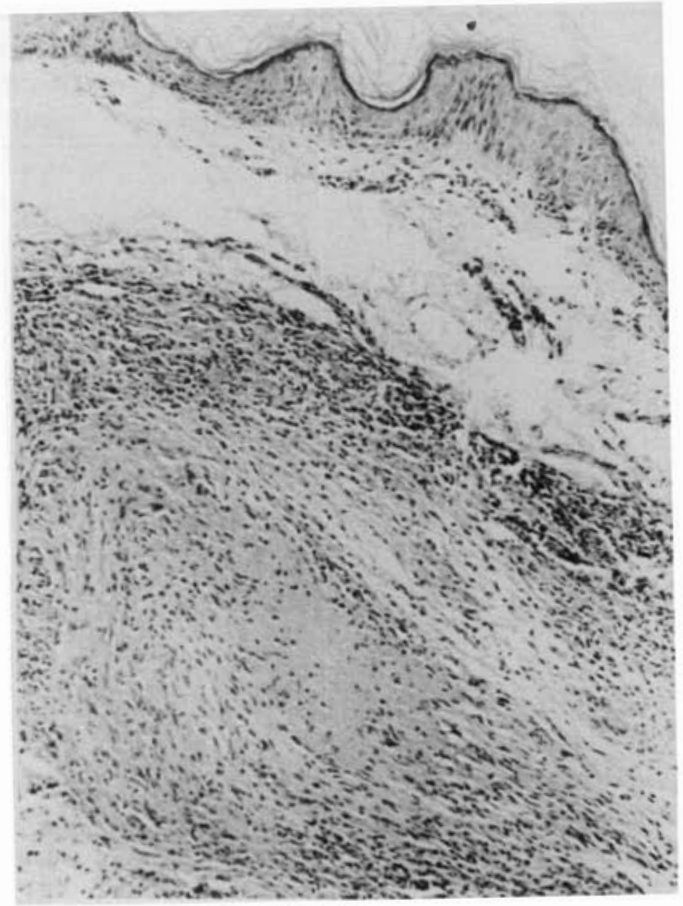

Figure 1. Typical granuloma in a tuberculoid case.

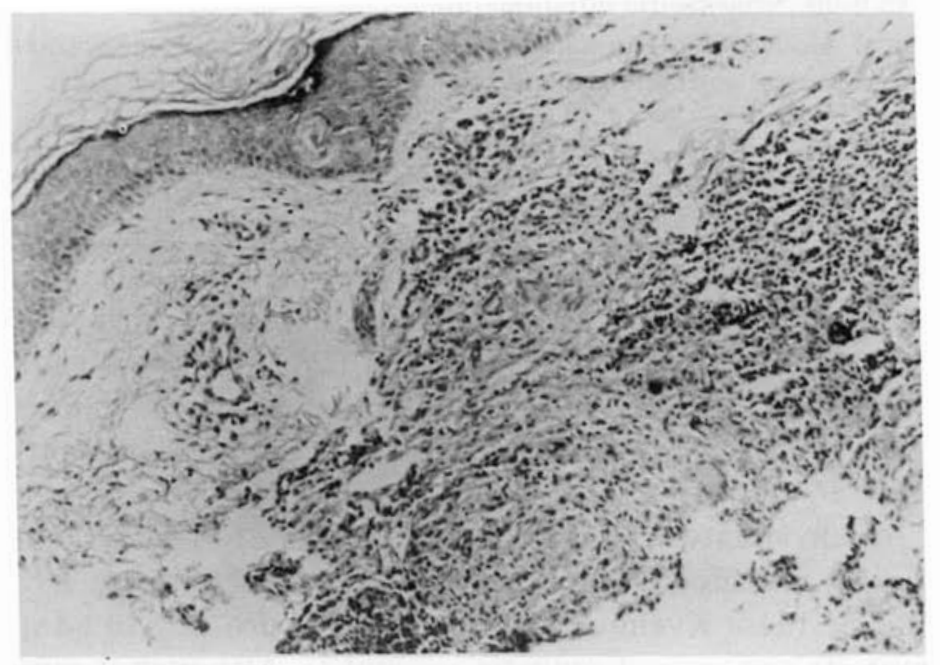

Figure 2. Typical granuloma with giant cells in a lepromatous case. 
of leprosy patients to intradermal injection of Kveim antigen is a special matter because in an international study 6,7 in which a validated Kveim material was used, it showed a high frequency of positive Kveim test reactions among Japanese. Similar results were reported by Pearson et al. ${ }^{14}$ and Rees ${ }^{15}$ in Japanese and Malay patients with lepromatous leprosy, and by Hurley et $a l .{ }^{31}$ in lepromatous leprosy and ENL. In contrast, Pearson et al., ${ }^{14}$ Rees $^{15}$ and Hopper and Stuettgen, ${ }^{32}$ using validated Kveim material, found no positive reactions among European, and Mendes et al. ${ }^{27}$ in the Brazilian leprosy patients.

In the present study, 2 of the 6 tuberculoid patients $(33 \%)$ gave positive histopathological response and 1 gave an equivocal result, whereas in the lepromatous group only 1 patient out of $15(6.6 \%)$ gave positive reaction and the result was equivocal in 2 . In the only study available from India, Krishnamurthy et al. ${ }^{18}$ found positive rates of $36 \%$ among tuberculoid patients and $25 \%$ among lepromatous patients. Thus, our results show lower frequency of positive Kveim tests than those in Japanese ${ }^{6,14,15}$ and South Indians. ${ }^{18}$

There is no clear explanation for the positive Kveim test reported in leprosy patients. It will be interesting to note that Bedi et al. ${ }^{33}$ examined skin biopsies from clinically normal looking skin of the scalp, axillae and groins in 20 treated lepromatous leprosy patients and found that up to $25 \%$ of the patients had well-formed foam cell granulomas. Further, Klokke et al. ${ }^{34}$ performed skin tests similar to Kveim tests on 7 patients with tuberculoid leprosy with a suspension of non-sarcoid human spleen and found that 3 of these patients had histologic evidence of granulomatous inflammation at the test site.

It appears that positive Kveim tests in leprosy patients could very well be due to the presence of occult granulomas present in the normal looking skin of these patients. The needle trauma could also be triggering or accelerating the granulomatous inflammation. It is suggested that further studies be carried out with inactivated Kveim antigen and normal saline as controls to finally settle the controversy of positive Kveim tests in leprosy.

\section{References}

${ }^{1}$ Bradstreet CMP, Dighere MW, Mitchell DN. The Kveim test: Analysis of results of tests using Colindale (K-12) materials. In: Siltzbach LE (ed), 7th International Conference on Sarcoidosis and Other Granulomatous Disorders, The New York Academy of Sciences, New York, 1976, p. 681.

2 Douglas AC, Wallace AC, Clark J, Stephens JH, Smith IE, Allan NC. The Edinburgh spleen: Source of a validated Kveim-Siltzbach test material. In: Siltzbach LE (ed), 7th International Conference on Sarcoidosis and Other Granulomatous Disorders, The New York Academy of Sciences, New York, 1976, p. 670.

${ }^{3}$ Hirsch JG, Nelson CT, Siltzbach LE. The Kveim Test, New Eng J Med, 1971, 284 : 1326.

${ }^{4}$ Israel HL, Goldstein RA. Relation of Kveim antigen reaction to lymphadenopathy; study of sarcoidosis and other diseases. New Eng J Med, 1971, 284: 345. 


\section{Surrinder Kaur et al.}

${ }^{5}$ Mitchell DN, Hinson KFW, Dyer NH, Willoughby JMT, Cannon P. Some recent observations on the Kveim reaction. In: Iwai K, Hosoda Y (eds), Proceedings of the 6 th International Conference on Sarcoidosis, University Park Press, Baltimore, Md, 1974, p. 90.

${ }^{6}$ Siltzbach LE. Results of Kveim testing. An International Kveim test study. Acta Med Scand, 176 (Suppl) 1964; No. 425: p. 178.

${ }^{7}$ Siltzbach LE. An international Kveim test study, 1960-66. La Sarcoidose, RAPP, IV ${ }^{3}$ Conf Intern; Masson et $C f^{e}$ edit., Paris, 1967, p. 201.

${ }^{8}$ Turiaf J, Menault M, Basset F, Jeanjean Y, Battesti JP. Absence of relation between Kveim test and adenopathies in sarcoidosis and other disease with lymph node localizations. In: Iwai K, Hosoda Y (eds), Proceedings of the 6th International Conference on Sarcoidosis, University Park Press, Baltimore, Md, 1974, p. 84.

${ }^{9}$ Williams E. The Kveim test in Brucellosis, In: Iwai K, Hosoda Y (eds), Proceedings of the 6th International Conference on Sarcoidosis, University Park Press, Baltimore, Md, 1974, p. 96.

10 Bradstreet CM, Dighere MG, Mitchell DN. Analysis of results of testing Colindale (K 19) materials, 1973-77. In: Williams W, Davies B (eds), Proceedings of the 8th International Conference on Sarcoidosis and Other Granulomatous Diseases, Alpha Omega Publishing Ltd, Cardiff, Wales, U.K., 1980, p. 674.

11 Kataria YP, Sharma OP, Israel L, Rogers M. Kveim antigen CR-I: Its sensitivity and specificity in sarcoidosis. A cooperative study. In: Williams WJ, Davies B (eds), Proceedings of the 8th International Conference on Sarcoidosis and Other Granulomatous Diseases, Alpha Omega Publishing Ltd, Cardiff, Wales, U.K., 1980, p. 660.

12 Middleton WG, Douglas AC. Further experience with Edinburgh prepared Kveim-Siltzbach test suspensions. In: Williams WJ, Davies B (eds), Proceedings of the 8 th International Conference on Sarcoidosis and Other Granulomatous Diseases, Alpha Omega Publishing Ltd, Cardiff, Wales, U.K., 1980, p. 655.

13 Turiaf J, Menault M, Battesi F, Jeanjean Y. The Kveim test: A personal experiment using an allergen obtained from a sarcoid splenomegaly. In: Wiliams WJ, Davies B (eds), Proceedings of the 8th International Conference on Sarcoidosis and Other Granulomatous Diseases, Alpha Omega Publishing Ltd, Cardiff, Wales, U.K., 1980, p. 678.

14 Pearson JMM, Pettit JHS, Siltzbach LE, Ridley DS, Hart PD, Rees RJW. The Kveim test in lepromatous and tuberculoid leprosy. Int J Lepr, 1969; 37: 372.

15 Rees RJW. The Kveim test in leprosy. Post Grad Med J 1970; 46: 486.

16 Siltzbach LE. The Kveim test in tuberculosis, berrylium disease, leprosy, and sarcoidosis. Amer Rev Resp Dis, 1964a; 90: 308.

17 Siltzbach LE. The significance of and specificity of the Kveim reaction. Acta Med Scand, 1976 (Suppl.) 1964b; No. 425, p. 74.

18 Krishnamurthy S, Verghese R, Job CK. The Kveim test in leprosy. Int J Lepr, 1975; 43: 333.

19 Ridley DS, Jopling WH. Classification of leprosy according to immunity. A five group system. Int J Lepr 1966; 34: 255.

20 Siltzbach LE, Ehrlich JC. The Nickerson-Kveim reaction in sarcoidosis. Amer J Med, $1954 ; 16: 790$.

21 Mitchell DN. The Kveim test in recent advances in clinical pathology. Recent Advances in Clinical Pathology. Dyke SC (ed), Boston: Little Brown and Co. Series V, p. 431.

22 Williams RH, Nickerson DA. Skin reactions in sarcoid. Proc Soc Exper Biol \& Med, 1935; 33: 402.

${ }^{23}$ Kveim A. En ng og Spesifik Kutan-Reackjon ved Boecks Sarcoid. Nord Med, 1941; 9: 169. 
Hurley TH, Bartholomeusz CL. Proceedings of the 5th International Conference on Sarcoidosis. Levinsky L, Macholde FC (eds), Prague, 1971, p. 343.

Siltzbach LE. Current status of Nickerson-Kveim Reaction. Amer Rev Resp Dis, 1961; 84: 89.

${ }^{26}$ Karlish AJ, Cox EV, Hampson F, Hemsted EH. Kveim test in Crohn's disease. (Correspondence). Lancet, 1970; 2: 977.

${ }^{27}$ Mendes E, Levy LH, de Ulhoa Cintra AB. Kveim test in patients suspected of sarcoidosis and in leprosy patients in a geographical area not yet investigated. Allergol Immunopath, 1976; IV: 45.

${ }^{28}$ Mitchell DN, Cannon P, Dyer NH, Hinson KFW, Willoughby JMT. The Kveim test in Crohn's disease. Lancet, 1969; 2: 571.

29 Mitchell DN, Cannon P, Dyer NH, Hinson KFW, Willoughby JMT. Further observations on Kveim test in Crohn's disease. Lancet, 1970; 2: 496.

30 Siltzbach LE. Surveillance of Kveim test results. In: Iwai K, Hosoda Y (eds), Proceedings of the 6th International Conference on Sarcoidosis, University Park Press, Baltimore, Md, 1974, p. 79.

31 Hurley TH, Sullivan JR, Hurley JV. Reaction to Kveim test material in sarcoidosis and other diseases. Lancet, 1975; 1: 494.

32 Hopper JE, Stuettgen G. The diagnostic value of skin tests with tissue extracts, especially in lepra and sarcoidosis. A study with lepromin, Kveim antigen, tuberculin in patients with common dermatoses, erythema nodosum, sarcoidosis and lepra, Immun Infelct 3, 36. Excerpta Medica (Dermatology \& Venereology) 1976; 30; 524 (Abstract).

33 Bedi TR, Kumar B, Kaur S. Histopathologic study of clinically normal appearing skin in lepromatous leprosy. Leprosy in India, 1979; 51: 78.

34 Klokke AH, Bhaktaviziam A, Subramaniam B. The isopathic phenomenon in infiltrated tuberculoid and macular tuberculoid leprosy. A comparative histologic study of the tissue response produced by cotton pellet implantation and lepromin injection. Int $J$ Lepr, 1967; 35: 477. 